\title{
PERSEPSI DAMPAK UJIAN DENGAN MCQ TERHADAP PROSES BELAJAR MAHASISWA FAKULTAS KEDOKTERAN
}

\author{
Irwin Aras*, Gandes Retno Rahayu**, Yayi Suryo Prabandari** \\ * Mahasiswa S2 IImu Pendidikan Kedokteran, Fakultas Kedokteran UGM \\ **Bagian Pendidikan Kedokteran, Fakultas Kedokteran UGM
}

\begin{abstract}
Background: Multiple choice question (MCQ) has been used widely as a method to assess the achievement of learning outcomes. MCQ as an assessment instrument may give both expected and unexpected impact. The research's objective is to identify the impacts of MCQs in term of the structure, content, information and regulation on the learning process of student at Medical Faculty Hasanuddin University

Method: The study was a descriptive survey involving 505 medical students from Hasanuddin University who were still in the academic phase, class of 2010, 2011 and 2012. Preliminary study was carried out to explore learning impacts caused by MCQs. Based on the result of preliminary study a questionnaire using rating scale was developed, consisting 92 items of possible learning impacts. Open ended questions were added to get free response from the students. The answers were classified into expected and unexpected learning impacts.

Results: The structure, content, information and regulation of the MCQ method gave expected impacts such as learning from many sources (74.4\%), group studying (96.2\%), mind mapping (37.9\%) and re-discussing the exam materials (96.2\%). It also gave unexpected impacts such as guessing the answer (44.8\%), only studying previous exams (93.5\%), cheating (33.7\%) and taking pictures of the exam papers (38.2\%).

Conclusion: Unexpected impacts may occur from the MCQ method, which structurally consists of item flaws, such as only assessing memorizing skills rather than the application of knowledge and incomplete information in the stem. The regulation, in the form of summative exam, will encourage students to prepare themselves more seriously if compared to the formative exam.
\end{abstract}

Keywords: MCQ, assessment impact, learning process

\section{ABSTRAK}

Latar belakang: Penggunaan multiple choice question (MCQ - soal pilihan berganda) sebagai metode untuk menguji pencapaian hasil akhir belajar saat ini sudah sangat luas. MCQ sebagai instrumen penilaian dapat menimbulkan dampak pembelajaran, baik yang diharapkan maupun tidak diharapkan. Penelitian ini bertujuan untuk mengetahui berbagai dampak struktur, isi, informasi dan regulasi ujian dengan MCQ terhadap proses belajar mahasiswa FK UNHAS.

Metode: Penelitian ini adalah survei deskriptif. Subjek adalah 505 mahasiswa FK Unhas fase akademik, yang terdiri dari angkatan 2010,

2011 dan 2012. Penyusunan instrumen penelitian didahului preliminary study untuk mengeksplorasi berbagai dampak pembelajaran dari metode MCQ. Berdasarkan studi tersebut disusun kuesioner yang berisi 92 item kemungkinan dampak pembelajaran menggunakan rating scale. Selain itu juga mengukur tanggapan mandiri (free response). Selanjutnya jawaban mahasiswa dikelompokkan menjadi 2 kelompok, yaitu dampak yang diharapkan dan yang tidak diharapkan.

Hasil: Struktur, isi, informasi dan regulasi dari soal berbentuk MCQ dapat menghasilkan dampak yang diharapkan seperti belajar dari berbagai sumber (74.4\%), belajar secara berkelompok (96.2\%), membuat mind mapping (37.9\%) dan mendiskusikan kembali materi yang telah diujikan (96.2\%). Adapun dampak yang tidak diharapkan berupa

Korespondensi: gandes_rr@hotmail.com 
menjawab dengan menebak-nebak saja (44.8\%), belajar soal saja (93.5\%), menyontek (33.7\%) atau memotret soal ketika ujian (38.2\%).

Kesimpulan: Dampak pembelajaran yang tidak diharapkan dapat muncul pada soal MCQ yang secara struktur mengandung item flares, yang isinya hanya menguji memorisasi, bukan aplikasi dari suatu ilmu, dan informasi soal yang tidak lengkap. Regulasi berupa ujian sumatif, akan mendorong mahasiswa mempersiapkan diri lebih sungguh-sungguh dibandingkan ujian formatif.

$\underline{\text { Kata kunci: MCQ, dampak ujian, proses belajar }}$

\section{PENDAHULUAN}

Penggunaan multiple choice question (MCQ - soal pilihan berganda) sebagai metode untuk menguji pencapaian hasil akhir belajar saat ini sudah sangat luas. Sejak SD hingga perguruan tinggi, bahkan sampai pada Uji Kompetensi Dokter Indonesia (UKDI), MCQ menjadi suatu metode yang sangat familiar baik bagi para pengajar maupun peserta didik. ${ }^{1}$

Bagi Fakultas Kedokteran Universitas Hasanuddin (FK Unhas), demikian pula FK lain di Indonesia, MCQ hingga saat ini masih dianggap sebagai metode yang paling tepat digunakan untuk menguji pencapian hasil belajar, khususnya untuk ranah pengetahuan. MCQ digunakan sebagai bentuk soal yang disajikan pada semua ujian mata kuliah dan memberikan kontribusi terbesar dalam membentuk nilai akhir (final mark). Metode ini umumnya dipilih karena dianggap paling tepat untuk mewakili luasnya pengetahuan yang harus diujikan, juga karena kepraktisan dalam penerapannya. ${ }^{2}$

MCQ sebagai instrumen penilaian, dapat dinilai berdasarkan karakteristik yang dimilikinya, salah satunya adalah instrumen tersebut memberikan dampak yang baik pada proses belajar pada mahasiswa (learning impact) yang mengikuti ujian tersebut atau tidak. ${ }^{3}$ Menurut Van Der Vleuten dan Schuwirth, ${ }^{4}$ dampak pembelajaran menjadi karakteristik yang sangat penting karena setiap instrumen, apapun bentuknya, dan setiap ujian, untuk apapun tujuannya, akan sangat mempengaruhi apa dan bagaimana mahasiswa belajar (assessment drives learning).

Bagi mahasiswa yang malas belajar, sebelum menghadapi ujian cukup dengan belajar dari soal-soal sebelumnya atau bahkan sama sekali tidak belajar, karena diyakini tetap akan bisa menjawab ketika menghadapi soal ujian. MCQ juga memungkinkan mahasiswa untuk mengoleksi soal-soal yang telah diujikan. Selain itu, ujian dengan MCQ tidak jarang membuat mahasiswa hanya fokus pada jawaban yang benar saja, tanpa melihat gambaran secara utuh, dan tak jarang mendorong mahasiswa untuk melakukan kecurangan dengan menyontek. $^{3}$

Menurut Roediger, McDermott \& McDaniel, ${ }^{5}$ kebanyakan dosen dan mahasiswa menganggap bahwa ujian adalah instrumen untuk mengetahui sampai sejauh mana mahasiswa belajar dan menentukan kelulusan mahasiswa saja. Padahal sesungguhnya, bila suatu instrumen penilaian didesain sebaik mungkin maka juga bisa meningkatkan kualitas belajar mahasiswa. ${ }^{5}$

Di FKUNHAS, sejak diberlakukannya format soal MCQ yang menggunakan vignette, nampak memberikan perubahan cara belajar pada mahasiswa secara bermakna. Hingga saat ini belum ada studi yang mengukur atau menggali dampak MCQ tersebut, baik pengaruh yang diharapkan maupun tidak diharapkan terhadap proses belajar mahasiswa. Penelitian ini bertujuan untuk mengetahui berbagai dampak struktur, isi, informasi dan regulasi ujian dengan MCQ terhadap proses belajar mahasiswa FK UNHAS.

\section{METODE}

Metode yang digunakan adalah survei deskriptif yang dilaksanakan pada bulan Januari tahun 2013. Rancangan ini diharapkan dapat memberikan informasi tentang berbagai dampak pembelajaran yang dihasilkan oleh MCQ. ${ }^{6}$ Subjek adalah 505 mahasiswa FK Unhas fase akademik, yang terdiri dari angkatan 2010, 2011 dan 2012. Penyusunan instrumen didahului dengan diskusi bersama 24 orang mahasiswa sebagai preliminary study untuk mengeksplorasi berbagai dampak pembelajaran dari metode MCQ. Berdasarkan studi awal 
tersebut, disusun kuesioner yang berisi 92 item mengenai kemungkinan dampak pembelajaran menggunakan rating scale dengan rentang selalu, sering, kadang-kadang, jarang, dan tidak pernah. Instrumen ini reliabel, dengan nilai Chronbach's alpha sebesar 0,841. Selain itu juga mengukur tanggapan mandiri (free response) yang dituliskan dengan kata-kata sendiri oleh subyek. ${ }^{6}$ Selanjutnya jawaban mahasiswa dikelompokkan menjadi 2 kelompok, yaitu dampak yang diharapkan (itntended impact) dan yang tidak diharapkan (unintended impact).

\section{HASIL DAN PEMBAHASAN}

Karakteristik umum subyek (Tabel 1) memperlihatkan proporsi mahasiswa perempuan selalu lebih banyak daripada laki-laki pada tiap angkatan. Proporsi mahasiswa angkatan 2010 yang memiliki rentang IPK 3,1-4,0 lebih besar dibandingkan dengan rentang 2,1-3,0. Sedangkan pada angkatan 2011 hal sebaliknya berlaku. Untuk angkatan 2012, proporsi terbesar adalah mereka yang berada pada rentang IPK 3,1-4,0. Pada ketiga angkatan, jalur masuk didominasi oleh jalur Seleksi Nasional Masuk Perguruan Tinggi Negeri (SNMPTN) dan Jalur Non-Subsidi (JNS).

Tabel 1. Distribusi karakteristik subyek tiap angkatan

\begin{tabular}{llccccccc}
\multirow{2}{*}{ Variabel } & \multirow{6}{*}{ Subgrup } & \multicolumn{7}{c}{ Angkatan } \\
\cline { 3 - 8 } & & & 2010 & \multicolumn{2}{c}{2011} & \multicolumn{2}{c}{2012} \\
\cline { 3 - 8 } & & $\mathrm{n}(104)$ & $\%$ & $\mathrm{n}(186)$ & $\%$ & $\mathrm{n}(215)$ & $\%$ \\
\hline \multirow{2}{*}{ Jenis Kelamin } & Laki-laki & 42 & 40.4 & 52 & 28.0 & 70 & 32.6 \\
& Perempuan & 62 & 59.6 & 134 & 72.0 & 145 & 67.4 \\
\hline IPK & $0,1-1,0$ & 1 & 1.0 & 0 & 0.0 & 5 & 2.3 \\
& $1,1-2,0$ & 1 & 1.0 & 15 & 8.1 & 37 & 17.2 \\
& $2,1-3,0$ & 40 & 38.4 & 105 & 56.4 & 63 & 29.3 \\
& $3,1-4,0$ & 62 & 59.6 & 66 & 35.5 & 110 & 51.2 \\
\hline Jalur Masuk & SNMPTN & 40 & 38.5 & 112 & 60,2 & 106 & 49.3 \\
& JPPB & 12 & 11.5 & 12 & 6,5 & 19 & 8.8 \\
& JNS & 52 & 50.0 & 62 & 33,3 & 90 & 41.9 \\
\hline
\end{tabular}

Dampak dari struktur soal MCQ berasal dari item flaws (Tabel 2), ${ }^{6}$ yaitu mahasiswa mampu menjawab suatu soal, bukan karena penguasaan terhadap materi, tetapi karena kemampuan untuk menebak jawaban yang benar (testwiseness). Selain itu, juga berasal dari kesulitan mahasiswa dalam menjawab soal MCQ, bukan oleh sulitnya materi yang diujikan, tetapi disebabkan oleh struktur soalnya (irrelevant difficulty). Selain itu, tipe soal, seperti mencocokkan, sebab-akibat dan tipe 1, 2, 3 dan 4 , juga memberikan pengaruh bagi mahasiswa, khususnya saat ujian.

Tabel 2. Dampak pembelajaran berkaitan struktur soal

\section{Diharapkan}

Tidak diharapkan

1. Menyortir pilihan yang tidak sesuai dengan kalimat pertanyaan.

2. Belajar dengan menghafalkan kata kunci pada saat belajar dan mencocokkannya dengan pilihan jawaban.

3. Tidak memilih pilihan yang mengandung istilah yang tidak mengerti artinya.
1. Memilih pilihan jawaban yang paling pendek atau panjang.

2. Menghindari pilihan yang panjang., karena seringkali menjebak.

3. Memilih pilihan yang familiar.

4. Tidak punya ide sama sekali, mengikuti perasaan saja. 
4. Memilih pilihan yang mengandung definisi atau tanggapan.

5. Memilih di antara pilihan yang memiliki kemiripan kalimat atau pengertian.

6. Memilih pilihan berdasakan yang paling banyak dijawab oleh teman ketika pembahasan soal setelah ujian.

7. Lebih menyiapkan diri sebelum ujian dengan cara belajar.

8. Mengeliminir pilihan yang mengandung istilah absolut "tidak pernah".

9. Tidak memilih pilihan yang tidak berhubungan dengan kasusnya.

10. Membaca dengan seksama, meski memakan waktu.

11. Memilih jawaban secara teliti, karena pilihan yang tersedia tidak harus terbagi pada setiap soal.

12. Fokus pada soal yang pertama meski memakan waktu.
5. Bingung karena tidak jelas apa yang ditanyakan.

6. Memilih pilihan yang mengandung istilah asing/ sulit.

7. Menyeleksi pilihan menggunakan kata-kata pada pertanyaan.

8. Melakukan "cap-cip-cup” (gambling) karena tidak tahu.

9. Mulai dengan membaca pertanyaan dulu, bila tidak bisa menjawab barulah membaca skenario (vignette).

10. Memilih pilihan yang merupakan pengulangan kata pada badan soal.

11. Memilih pilihan yang paling sering diulang katanya.

12. Tidak membaca soal lagi, karena terlalu panjang.

13. Memilih yang lebih kompleks informasinya.

14. Menghindari yang mengandung kata frekuensi, karena sering menjebak dan multi interpretasi.

15. Memilih pilihan yang ada angkanya karena cenderung lebih pasti.

16. Melewatkan dulu, nanti pada menit-menit akhir baru dikerjakan.

17. Tidak mempertimbangkan pilihan jawaban BSSD.

18. Memilih BSSD bila sudah last minute.

19. Menganggap soal seerti BSSD sebagai bonus, tidak masalah kalau salah.

20. Memilih berdasarkan pola jawaban yang sudah ada pada lembar jawaban.

21. Mengutamakan soal yang diketahui, lalu mencocokkan sisanya.

22. Mendistribusikan semua pilihan pada setiap soal.

23. Cenderung menilai tata bahasanya dalam menjawab.

24. Memilih opsi E bila tidak tahu jawabannya, karena sudah pasti mencakup opsi yang benar.

25. Memakai strategi; cek dulu no. 1 dan 4, lalu cek no. 2. Tidak perlu membaca semuanya.

26. Menggunakan informasi pada soal berikutnya untuk menjawab soal, karena biasanya ada informasi tambahan.
Disadari atau tidak oleh pihak fakultas, MCQ telah dan akan mempengaruhi atau membentuk 'apa' dan 'bagaimana' mahasiswa belajar (steering effect), karena penggunaannya yang luas. Hal tersebut dapat dicapai secara efektif bila ujian didasarkan pada test blueprint yang telah disusun. ${ }^{2}$
Secara umum, dari komentar bebas berkaitan kualitas soal MCQ yang sudah diujikan selama ini, responden menyatakan cukup baik. Masih adanya bentuk soal yang tidak berskenario, mendorong mahasiswa menghafal saja. Namun, ada responden yang mengakui kesulitan dalam menilai kualitas soal dikarenakan soal sering berulang. 
Ujian dengan metode MCQ dapat menghasilkan dampak yang tidak diharapkan dengan membuat mahasiswa memilih jawaban secara tricky, yang dihasilkan dari struktur yang mengandung testwiseness. Faktor utama yang menyebabkan testwiseness adalah biasanya penulis soal lebih terfokus pada jawaban benar, sehingga seringkali mengabaikan distraktornya. ${ }^{7}$ Syarat suatu distraktor dikatakan baik pada jenis ujian satu jawaban terbaik (one best answer) adalah bila homogen dengan pilihan yang benar (misalnya semua jenis diagnosis, tindakan, hasil lab, dan lain-lain), sehingga semua option menunjukkan kemungkinan untuk dipilih.

Hal yang berkaitan dengan struktur tersebut menimbulkan dampak yang tidak diharapkan, yaitu mahasiswa terdorong untuk memilih jawaban secara tricky, seperti memilih pilihan yang paling pendek atau paling panjang, yang mengandung istilah asing, menyeleksi pilihan dengan kata-kata pada vignette dan gambling atau asal tebak.

Dampak diharapkan yang timbul misalnya berupa lebih menyiapkan diri sebelum ujian dengan cara belajar, membaca dengan seksama meski memakan waktu, belajar dengan menghafalkan kata kunci pada saat belajar dan mencocokkannya dengan pilihan jawaban, dan memilih pilihan berdasakan yang paling banyak dijawab oleh teman ketika pembahasan soal setelah ujian.

Isi soal yang yang hanya menguji aspek hafalan, lebih mendorong mahasiswa untuk menghafal saja (Tabel 3). Apa lagi bila soal yang diujikan merupakan soal yang sudah pernah diujikan sebelumnya, walau pun pada angkatan yang berbeda. Hal tersebut dimungkinkan, sebagaimana diakui pada free comment, karena mahasiswa memiliki kebiasaan untuk mengoleksi soal tiap kali setelah ujian. Sebaliknya bila dipapar dengan soal berupa aplikasi, justru mendorong mahasiswa untuk belajar secara berkelompok dan memanfaatkan banyak sumber belajar selain bahan kuliah, seperti modul, buku teks, jurnal dan bertanya pada dosen pengampu. Mahasiswa merasa senang dengan soal seperti ini, karena tertantang berperan sebagai dokter sebenarnya.

Tabel 3. Dampak pembelajaran berkaitan isi soal

Diharapkan

Tidak diharapkan

1. Harus belajar dengan menghafal.

2. Belajar dengan menghafal kata kunci dan mencocokkannya dengan pilihan saat ujian.

3. Memilih pilihan yang paling logis.

4. Lebih termotivasi untuk belajar kelompok dengan soal-soal dan bahan kuliah.

5. Memulai belajar dengan menjawab soal-soal lama, lalu mencocokkannya dengan bahan kuliah atau textbook.

6. Lebih terdorong untuk belajar dari modul dalam tutorial.

7. Lebih terdorong untuk belajar dari slide dan penjelasan serta bertanya pada dosen saat kuliah.

8. Belajar dari berbagai sumber (textbook, journal, dll).

9. Lebih tertantang karena seakan bertindak sebagai seorang dokter.

10. Berpikir secara bertahap sebelum menjawab.

11. Terdorong mengoleksi soal dengan menghafal dan mengumpulkan setelah ujian.

12. Belajar dengan berpatokan pada Standar Kompetensi Dokter Indonesia (SKDI).
1. Memilih pilihan yang paling tidak homogen/mirip.

2. Lebih terdorong mengoleksi soal dengan memotret soal ketika ujian, karena susah dihafal. 
Lanjutan tabel 3. Dampak pembelajaran berkaitan isi soal

13. Harus belajar semua yang diajarkan, tanpa melihat level kompetensinya.

14. Belajar dengan membahas soal-soal sebelumnya bersama teman-teman.

15. Membagi tugas untuk menjawab soal-soal sebelumnya, lalu belajar kelompok untuk membahasnya.

16. Mencari di textbook untuk soal-soal yang belum terjawab.

17. Mencari di jurnal untuk soal-soal yang belum terjawab.

Konsep yang ditanyakan sebaiknya fokus pada realitas yang akan dihadapi oleh seorang dokter. Untuk itu hindari pertanyaan yang sifatnya menguji fakta secara trivial. Penulisan soal yang disertai vignette klinik akan mendorong mahasiswa untuk mengintegrasikan pengetahuan dasar dan klinik, tidak hanya dalam hal kemampuan memorisasi saja, tapi juga berkaitan clinical reasoning, problem solving dan medical decision making. ${ }^{7}$

Belajar dari soal-soal sebelumnya, walau pun cukup membantu mahasiswa mempersiapkan diri menghadapi ujian berikutnya, juga memiliki dampak negatif. Meskipun jawaban benar telah dipilih, namun membaca distraktor berulang kali membuat mereka nampak benar kemudian. ${ }^{8}$ Akibat yang lain adalah option salah, dalam istilah lain disebut sebagai multiple choice lures, meningkat peluangnya untuk dipilih sebagai jawaban benar pada tes berikutnya. Efek ini makin besar pada materi yang tidak dipelajari sebelumnya. ${ }^{9}$ Untuk mengatasi hal tersebut dapat dilakukan, ${ }^{9}$ pertama; berikan umpan balik segera setelah menjawab atau ujian. Saat ini sudah ada aplikasi berbayar yang disebut IFAT (Immediate Feedback Test) yang berbasis komputer. Setiap jawaban benar akan ditandai dengan bintang. Kedua, menyediakan opsi 'tidak tahu' dan disertai hukuman pengurangan nilai untuk jawaban salah.

Semua bentuk informasi suatu soal, baik narasi, grafik atau pun tabel, yang terpenting bahwa informasi tersebut lengkap sehingga membantu mahasiswa menyelesaikan ujian. Soal MCQ yang isinya berupa grafik dan tabel tentu dirasakan sangat membantu untuk menjawab bagi mahasiswa yang tahu membacanya. Sebaliknya, walaupun hanya sedikit, bagi yang tidak tahu tentu akan kebingungan (Tabel 4).

Tabel 4. Dampak pembelajaran berkaitan informasi soal

1. Belajar soal lama dengan mengidentifikasi semua pilihan untuk antisipasi berulang lagi.

2. Saya menggunakan informasi dari grafik untuk menjawab soal seperti ini.

3. Saya menggunakan informasi dari tabel untuk menjawab soal seperti ini.

4. Saya menjawab dengan fokus pada angka yang disajikan pada tabel
1. Melakukan "cap-cip-cup" (gambling) karena tidak tahu.

2. Saya menebak-nebak saja menghadapi soal seperti ini, karena tidak tahu membaca grafik. 
Ketidaklengkapan informasi soal dapat mendorong mahasiswa untuk gambling dalam menjawab. Seringkali bila disadari oleh dosen, soal seperti ini akan menjadi bonus, dalam hal ini semua jawaban untuk item tersebut dinyatakan benar. Tentu hal ini, walaupun disenangi oleh mahasiswa, tetapi tidak akan mencapai tujuan ujian atau penilaian tersebut.
Sebagian besar responden mengakui pengaruh yang muncul dari ujian sumatif adalah mengalokasikan waktu belajar lebih banyak, belajar bahan kuliah, lebih fokus pada- materi ujian dan belajar kelompok. Sebaliknya hanya sedikit yang berbagi tugas sebagai narasumber dan mengerjakan soal lama, membuat mind mapping dan bahkan mengakui kemungkinan akan menyontek karena menentukan kelulusan (Tabel 5).

Tabel 5. Dampak pembelajaran berkaitan regulasi soal

Diharapkan

Tidak diharapkan

1. Mengalokasikan waktu untuk belajar lebih banyak.

2. Mempelajari bahan kuliah lebih banyak.

3. Belajar lebih fokus pada apa yang akan diujikan.

4. Belajar kelompok dengan membagi topik, lalu berdiskusi.

5. Sejak awal sharing tanggung jawab membuat catatan kuliah.

6. Berbagi tanggung jawab sebagai narasumber tiap topik materi pelajaran.

7. Berbagi tanggung jawab untuk mengerjakan soalsoal sebelumnya, lalu didiskusikan.

8. Membuat mind mapping setiap materi kuliah.

9. Belajar pada topik tertentu saja, sesuai bahan responsi/ujian.

10. Memberikan catatan khusus pada setiap penjelasan praktikum karena seringkali dosen/asisten memberikan intonasi pada konsep yang penting, sebab biasanya menjadi soal ketika responsi/ujian.

11. Menyenangi ujian responsi karena memberi kesempatan untuk memahami suatu konsep secara bertahap (nyicil), tidak sekaligus.

12. Lebih memilih belajar sendiri saja sebelum ujian ini, karena waktu sangat terbatas dan bahannya juga sedikit saja.
Dibandingkan dengan yang bersifat formatif, ujian sumatif cenderung mendorong mahasiswa untuk mempersiapkan diri lebih baik. Dampak yang muncul berupa penjadwalan belajar yang teratur, belajar berkelompok, menggunakan berbagai sumber pembelajaran, hingga belajar dengan membuat mind mapping. Mengingat ujian sumatif sangat menentukan kelulusan mahasiswa, segala upaya akan dilakukan, termasuk hal yang negatif seperti memotret soal, bahkan dalam keadaan terdesak mereka dapat saja menyontek
1. Bisa saja nyontek (cheating) bila terdesak, mengingat ujian ini sangat menentukan kelulusan saya. (cheating) demi untuk mendapat jawaban yang benar dari teman.

Namun beberapa mahasiswa cukup menyenangi ujian yang bersifat formatif, selain dapat memantau perkembangan pengetahuan (feedback), juga ujian ini tidaklah memberikan tekanan psikologis yang besar bagi mahasiswa. Sebagian menyenangi karena bisa belajar lebih fokus karena materi yang diujikan sedikit saja, sehingga bisa untuk menyicil materi untuk kepentingan ujian akhir. 
Adapun ujian yang bertujuan untuk memantau kemajuan mahasiswa (formatif), bagi sebagian besar responden mendorong mereka fokus belajar pada topik tertentu sesuai bahan ujian, lebih memilih belajar sendiri dan belajar jadi bertahap (menyicil).

\section{KESIMPULAN}

Dampak pembelajaran yang tidak diharapkan dapat muncul pada soal MCQ yang secara struktur mengandung item flaws, yang isinya hanya menguji memorisasi, bukan aplikasi dari suatu ilmu, dan informasi soal yang tidak lengkap. Regulasi berupa ujian sumatif, akan mendorong mahasiswa mempersiapkan diri lebih sungguh-sungguh dibandingkan ujian formatif.

\section{SARAN}

Untuk menghasilkan dampak pembelajaran yang diharapkan dan meminimalkan sebaliknya, perlu dilakukan pelatihan secara berkala bagi dosen untuk meningkatkan kemampuan dalam membuat soal MCQ yang berkualitas. Selain itu, dosen hendaknya berdasar pada SKDI dalam memberikan kuliah dan menyusun soal ujian. Serta mahasiswa diharapkan jangan hanya terfokus pada belajar soal ketika persiapan ujian, tetapi tetap memanfaatkan sumber pembelajaran lainnya, seperti buku teks, jurnal dan lainnya, sehingga dapat memahami ilmu kedokteran secara komprehensif, tidak hanya secara trivial.

\section{DAFTAR PUSTAKA}

1. Page, G. Handbook on competency-based assessment in Indonesian medical schools. In Press; 2007.

2. McCoubrie, P. Improving the fairness of multilechoice question: a literature review. Med Teach. 2004;26(8), pp. 709-12.

3. Shumway, J.M \& Harden, R.M. AMEE Guide no. 25: the assessment of learning of outcomes for the competent and reflective physician. Medical Teacher. 2003;25(6), pp. 569-84.

4. Van Der Vleuten, C.P.M \& Schuwirth, L.W.T. Assessing professional competence: from methods to programmes. Medical Education. 2005; 39, pp. 309. 17.

5. Roediger, H.L. III., McDermott, K.B. \& McDaniel, M.A. Using testing to improve learning and memory. In Press; 2010.

6. Gay, L.R \& Airasian, P. Descriptive research. In : Educational research: competencies for analysis and application. New Jersey: Prentice-Hall, Inc. 2000; pp. 275-314.

7. Case, S.M \& Swanson, D.B. Constructing written test questions for the basic and clinical sciences: Multiple-choiceitem formats. $3^{\text {rd }}$ ed. Philadelphia: National Board of Medical Examiners. 1998; p. 16.

8. Marsh, E,J., Roediger, H,L. III., Bjork, R.A., \& Bjork, E.L. The memorial consequences of multile-choice testing. Psyconomic Bulletin and Review. 2007;14(2), pp194-9.

9. Roediger, H.L. III., \& Marsh, E.J. The positive and negative consequences of ultiple-choice testing. Journal of Experiental Psycologicy: Learning, Memory $\mathcal{B}$ Cognition. 2005;31(5), pp 1155-9. 